\title{
Characteristics Evaluation of Commercial Fruit Tea Extracts in Korea
}

Ah-Ra Hwang ${ }^{1}$, Myung-Ryun $\mathrm{Han}^{2}$, Ae-Jung $\mathrm{Kim}^{1 *}$

${ }^{1}$ Department of Nutrition Therapy, Graduate School of Alternative Medicine, Kyonggi University, Seoul, Korea

${ }^{2}$ Department of Baking Science \& Technology, Hyejeon College, Hongsung-gun, Chungchengnam-do, Korea

\author{
*Corresponding author: Ae-Jung Kim, \\ Department of Nutrition Therapy, Graduate \\ School of Alternative Medicine, Kyonggi \\ University, 24, Kyonggidae-ro, 9-gil, \\ Seodaemun-gu, Seoul 03746, Korea \\ Tel.: +82 23905044 \\ Fax: +8223905078 \\ Email: aj5249@naver.com
}

Received November 15, 2021 Revised November 25, 2021 Accepted December 06, 2021 Published December 30, 2021

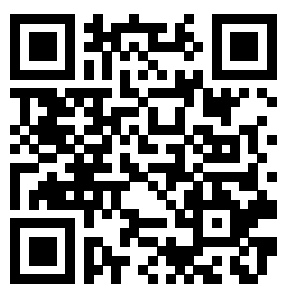

\begin{abstract}
Purpose: We evaluated the physicochemical characteristics and antioxidant activity of 21 types of fruit tea extract that are consumed in Korea. The data were analyzed and curated for the development of processed products using tea in the future. Methods: After extraction using hot water at $70^{\circ} \mathrm{C}$, we analyzed the physicochemical properties including color and $\mathrm{pH}$, as well as the antioxidant activity (total flavonoid content, DPPH scavenging activity, and $\alpha$-glucosidase inhibitory activity). Results: Calamansi tea exhibited the lowest brightness with a beet-red appearance, and a yellowness that was significantly higher in jujube and radish. The $\mathrm{pH}$ ranged from 3.04 to 7.18 and most samples were in an acidic state. Of these, the pH of schizandra fruit tea was the lowest at $3.04 \pm 0.01$. The total flavonoid content was the highest in calamansi at $217.87 \pm 1.45 \mathrm{QE} / \mathrm{g}$, whereas that of cacao nibs was the lowest at $29.04 \pm 0.70 \mathrm{QE} / \mathrm{g}$. The $\alpha$-glucosidase inhibitory activity of Chinese quince was the highest at $59.96 \% \pm 0.22 \%$. Conclusion: We obtained basic data for several fruit tea extracts by analyzing the physicochemical properties and antioxidant activities. We anticipate that these results will represent useful data for blending fruits for tea product development.
\end{abstract}

Keywords: Tea, Fruit tea, Commercial tea, Physicochemical property, Antioxidative property

\section{Introduction}

차는 차나무의 잎으로부터 얻는 것으로 수천년 전부터 음용되어온 음료로 전세계에서 다양한 형태로 판매되고 있고(Cao et al., 2006) 우리나라도 예로부터 건강을 위한 기능성 음료로 다류를 액체상태로 음용하여 왔으며 훌륭한 차문화 또한 간직하고 있다(Moon \& Park, 1995). 국내 대학생의 $71.6 \%$ 는 월 1 회 차를 음용하고 있으며 거의 매일 음용하는 경우도 $30.5 \%$ 에 달한다고 한다(Ko \& Park, 2017).

차는 발효 공정에 따라 녹차와 같은 비발효차, 홍차와 같은 발효 차, 반발효차로 분류되는 우롱차로 구분하고 있고 재배되는 지역의 기후, 토양, 농업 관행, 식물 자체의 유전적인 특성에 따라 구성성분 의 함량이 달라지게 된다고 한다(Graham, 1992). 뿌리, 줄기, 잎 등 차 제조 시 사용하는 부위에 따라 구성성분의 함량 차이와 함께 이화 학적 특성이나 항산화 활성 또한 다르게 나타난다.

차의 대표적 성분은 페놀성 화합물(phenolic compound)과 쓴맛을
내는 카페인(caffeine)이다. 차의 수용성 비타민 성분으로는 비타민 $\mathrm{C}$, 비타민 $\mathrm{B}_{1}$, 비타민 $\mathrm{B}_{2}$ 와 비타민 $\mathrm{A}$ 로 전환이 가능한 $\beta$-카로틴, 비 타민 $\mathrm{E}$ 과 같은 지용성 비타민 성분과 함께 아미노산 등도 차에 함유 되어 있다(Shin et al., 2011). Legeay et al. (2015)의 연구에 의하면 적어도 차의 폴리페놀 성분 중 $80 \%$ 는 플라보노이드 성분이라고 한 다.

차의 건강기능성과 관련해서는 항당뇨(Fang et al., 2015; Yoo et al., 2021), 항산화(Imran et al., 2018; Jung et al., 2019; Lee et al., 2021), 항비만(Snoussi et al., 2014) 및 대사증후군 발병 예방 및 감소 효과(Liu et al., 2017) 등에 대한 연구 결과가 보고된 바 있 다. 차에 포함된 페놀성 화합물인 플라보노이드는 카테킨 화합물로 인체내에서는 활성산소종을 제거하며 금속이온을 킬레이트 하는 효 과와 더불어 항산화, 항염증 및 체내 대사에 관여하는 생리활성 물질 로 인지질 대사, 인슐린 저항성, 염증 및 산화적 스트레스 등에 긍정 적인 영향을 미치는 것으로 알려져 있다(Van de Wier et al., 2017). 
현대인들의 서구화된 식습관 변화는 성인병에 대한 유병율을 높 이고 있으며 이로 인해 현대인들은 자연지향적 식생활에 대해 보다 많은 관심을 가지게 되었으며 연구자들은 액상의 건강음료로 알려 진 차에 대한 효과가 이미 여러 연구에서 입증된 바 있다(Kim et al., 2005).

복부 비만, 고혈압, 고혈당증, 이상 지질 혈증 등과 같은 위험 인자 들은 심혈관계 질환 및 제 2형 당뇨병의 위험성을 증가시키게 된다. 이러한 위험 인자들이 군집하여 발생하는 현상을 대사증후군이라고 한다(Levantesi et al., 2005). Legeay et al. (2015)의 연구에 의하면 대사증후군의 전 세계적 유병율은 20-25\%로 상당히 높은 상태라 하 였고 Grundy et al. (2006)의 연구에 의하면 현재까지 대사증후군 발 병에 가장 중요한 위험 인자로 손꼽히는 것은 복부 비만과 인슐린 저 항성이라고 한다. 대사증후군을 구성하는 위험 인자들은 높은 산화 스트레스를 특징으로 하며(Morelli et al., 2018), 높은 산화 스트레스 는 대사증후군 발병에 영향을 끼친다(Rösen et al., 2001).

본 연구에서는 한국에서 다소비 되고 있는 열매를 이용한 차류의 이화학적 특성과 항산화 활성을 분석 향후 차를 이용한 가공제품 개 발 시 필요한 기초자료를 마련하고자 하였다.

\section{Methods}

\section{1. 재료}

본 연구에서 사용한 열매 이용 다류는 개별 포장된 단일 침 출용 차로 경기도 소재의 대형 마트에서 구입한 다음 차용 티 백(가로 $\times$ 세로, $3.0 \times 3.0 \mathrm{~cm}$ )에 $3.0 \mathrm{~g}$ 씩 소분하여 밀봉한 것 을 상온에 저장하면서 분석에 사용하였다. 21종의 다류는 팥 (adzuki bean, Cheonnyeonnongwon, Korea), 비트(beet, Cheonnyeonnongwon, Korea), 여주(bitter gourd, Harinfood, Korea), 메밀(buckwheat, Damtuh, Korea), 카카오닙스(cacao nibs, Cheonnyeonnongwon, Korea), 깔라만시(calamansi, Botem, Korea), 결명자(cassia seed, Joeunyakcho, Korea), 차 가버섯(chaga mushroom, Cheonnyeonnongwon, Korea), 모과 (chinese quince, Orgavu, Korea), 유자(citron, Damtuh, Korea), 귤피(citrus unshiu peel, Cheonnyeonnongwon, Korea), 돼지 감자(jerusalem artichoke, Bangatgancheonnyeon, Korea), 대 추(jujube, Cheonnyeonnongwon, Korea), 구기자(Lycii fructus, Cheonnyeonnongwon, Korea), 노니(noni, Cheonnyeonnongwon, Korea), 헛개나무(oriental raisin tree, Dasoni, Korea), 무(radish, Bangatgancheonnyeon, Korea), 로즈힙(rose hip, Karauter Mix $\mathrm{GmbH}$, Germany), 홍화씨(safflower seed, Goesanyakcho, Korea), 오미자(schizandra, Cheonnyeonnongwon, Korea), 작두콩(sword bean, Bangatgancheonnyeon, Korea)이다.

\section{2. 열매차 열수 추출물의 이화학적 특성}

1) 열매차 열수 추출물 제조

추출에 사용한 물은 정수된 생수를 한번 끓인 다음 $70^{\circ} \mathrm{C}$ 로 냉각한 온수 $100 \mathrm{~mL}$ 를 가하여 $3 \mathrm{~min}$ 간 용출시켜 추출물을 제조한 다음 이 화학 특성 및 생리활성 분석에 사용하였다.

\section{2) Color value}

색도는 색차계(Chroma Meter, CR-300; Minolta, Japan) 를 사용하여 명도(L*, lightness), 적색도(a*, redness), 황색도(b*, yellowness) 값을 측정하였다. 각 시료 당 3 회 반복 측정하여 그 평 균값을 구하였고, 이때 사용한 표준 백색판의 조건은 $\mathrm{L}=96.82, \mathrm{a}=-$ $1.63, \mathrm{~b}=3.20$ 이었다.

\section{3) $\mathrm{pH}$}

pH는 pH meter (Lab 870; Schott Instruments, Germany)로 3 회 측정한 결과의 평균과 표준편차를 구하였다.

\section{3. 열매차 열수 추출물의 생리활성}

1) Total flavonoid content

총 플라보노이드 함량은 Davis (1947)의 방법에 따라 측정하였다. 추출물 $100 \mu \mathrm{L}$ 에 diethylene glycol (Daejung, Korea) 1,000 $\mu \mathrm{L}$ 를 첨가하여 혼합한 다음 $1.0 \mathrm{~N} \mathrm{NaOH}$ (Sigma-Aldrich, USA) 용액 10 $\mu \mathrm{L}$ 를 첨가한 후 $37^{\circ} \mathrm{C}$ 에서 $1 \mathrm{~h}$ 동안 반응시켰다. 이를 분광광도계를 이용 $420 \mathrm{~nm}$ 에서 흡광도를 측정하였다. 표준물질은 quercetin을 사 용하여 작성한 표준곡선으로부터 총 플라보노이드 함량을 계산하였 다.

\section{2) $D P P H$ radical scavenging activity}

1,1-diphenyl-2-picryl hydrazyl (DPPH; Sigma-Aldrich) radical 소거능은 Blois (1958)의 방법을 변형하여 실시하였다. 시료 $100 \mu \mathrm{L}$ 에 $1.5 \times 10^{-1} \mathrm{mM} \mathrm{DPPH}$ 용액 $100 \mu \mathrm{L}$ 를 가하여 상온의 암 실에서 $30 \mathrm{~min}$ 간 반응시킨 후 microplate reader (Tecan Infinite M200 Pro; GreenMate Bio, Korea)를 이용하여 $517 \mathrm{~nm}$ 에서 흡광 도를 측정하였다.

\section{3) $\alpha$-Glucosidase inhibition activity}

$\alpha$-Glucosidase 억제능은 Li et al. (2005)의 방법을 변형하여 측 정하였다. 96 well plate의 각 well에 sample $20 \mu \mathrm{L}$ 와 $100 \mathrm{mM}$ phosphate buffer (pH 6.8) (Daejung) $50 \mu \mathrm{L}$ 와 $\alpha$-glucosidase (0.2 unit $/ \mathrm{mL}$ ) (Sigma-Aldrich)를 $10 \mathrm{mM}$ phosphate buffer $(\mathrm{pH}$ 6.8) (Daejung) $10 \mu \mathrm{L}$ 를 첨가한 다음 $37^{\circ} \mathrm{C}$ 에서 $5 \mathrm{~min}$ 동안 preincubation을 시켰다. 기질로는 $100 \mathrm{mM}$ phosphate buffer $(\mathrm{pH}$ 6.8) (Daejung)에 녹인 $2.5 \mathrm{mM} \mathrm{p}$-nitrophenyl $\alpha$-D-glucopyranoside ( $p \mathrm{NPG}$; Sigma-Aldrich) $20 \mu \mathrm{L}$ 를 사용하여 $37^{\circ} \mathrm{C}$ 에서 $15 \mathrm{~min}$ 동안 
Table 1. The color values and appearance of commercial fruit teas extracted hot water at $70^{\circ} \mathrm{C}$

\begin{tabular}{|c|c|c|c|c|}
\hline Name of fruit tea & Appearance & $\mathrm{L}^{*}$ (Lightness) & $a^{*}$ (redness) & $\mathrm{b}^{*}$ (yellowness) \\
\hline Adzuki bean & & $63.12 \pm 0.01^{1 \mathrm{~g} 2)}$ & $-0.62 \pm 0.01^{1)(2)}$ & $4.79 \pm 0.01^{r}$ \\
\hline Beet & & $34.15 \pm 0.00^{\mathrm{s}}$ & $42.46 \pm 0.04^{a}$ & $22.87 \pm 0.04^{e}$ \\
\hline Bitter gourd & & $58.84 \pm 0.01^{\mathrm{m}}$ & $-1.86 \pm 0.02$ & $17.16 \pm 0.01^{i}$ \\
\hline Buckwheat & & $63.98 \pm 0.09^{e}$ & $-3.10 \pm 0.01^{a}$ & $8.12 \pm 0.06^{n}$ \\
\hline Cacao nibs & & $63.32 \pm 0.06^{f}$ & $-0.75 \pm 0.03^{h}$ & $4.17 \pm 0.02^{t}$ \\
\hline Calamansi & & $54.73 \pm 0.02^{r}$ & $0.05 \pm 0.02^{d}$ & $21.61 \pm 0.03^{f}$ \\
\hline Cassia seed & & $59.45 \pm 0.07^{\prime}$ & $-1.82 \pm 0.03^{\prime}$ & $23.20 \pm 0.24^{d}$ \\
\hline Chaga mushroom & & $55.09 \pm 0.05^{p}$ & $-0.67 \pm 0.01 g$ & $26.39 \pm 0.01^{c}$ \\
\hline Chinese quince & & $65.79 \pm 0.02^{\mathrm{a}}$ & $-1.10 \pm 0.04^{i}$ & $4.66 \pm 0.02^{s}$ \\
\hline Citron & & $64.53 \pm 0.05^{c}$ & $-2.02 \pm 0.05^{\mathrm{m}}$ & $6.28 \pm 0.13^{p}$ \\
\hline Citrus unshiu peel & & $63.17 \pm 0.05^{\mathrm{g}}$ & $-3.74 \pm 0.03^{r}$ & $12.26 \pm 0.08$ \\
\hline Jerusalem artichoke & & $61.81 \pm 0.01^{\mathrm{h}}$ & $-2.32 \pm 0.01^{\circ}$ & $14.32 \pm 0.02^{k}$ \\
\hline Jujube & & $57.32 \pm 0.03^{\circ}$ & $-0.52 \pm 0.02^{\mathrm{e}}$ & $28.46 \pm 0.19^{b}$ \\
\hline Lycii fructus & & $60.17 \pm 0.02^{k}$ & $-2.08 \pm 0.03^{n}$ & $18.56 \pm 0.02^{h}$ \\
\hline Noni & & $61.03 \pm 0.01^{j}$ & $-1.16 \pm 0.01^{j}$ & $16.06 \pm 0.02^{j}$ \\
\hline Oriental raisin tree & & $58.61 \pm 0.01^{n}$ & $-1.45 \pm 0.01^{k}$ & $19.33 \pm 0.03^{g}$ \\
\hline Radish & & $55.02 \pm 0.01^{9}$ & $1.72 \pm 0.03^{b}$ & $35.37 \pm 0.02^{a}$ \\
\hline Rose hip & & $63.97 \pm 0.02^{\mathrm{e}}$ & $-1.10 \pm 0.02^{i}$ & $5.75 \pm 0.05^{a}$ \\
\hline Safflower seed & & $65.60 \pm 0.02^{b}$ & $-1.09 \pm 0.03^{i}$ & $2.67 \pm 0.01^{\mathrm{u}}$ \\
\hline Schizandra & & $61.42 \pm 0.01^{i}$ & $1.05 \pm 0.02^{c}$ & $7.59 \pm 0.07^{\circ}$ \\
\hline Sword bean & & $64.36 \pm 0.02^{d}$ & $-2.43 \pm 0.01^{p}$ & $8.76 \pm 0.01^{m}$ \\
\hline
\end{tabular}

${ }^{11}$ Mean \pm S.D. $(\mathrm{n}=3) ;{ }^{2}$ Means with different letters in the same column are significantly different at $p<0.05$ by Duncan's multiple range test. 
incubation 시켰다. 이후 0.2 M sodium carbonate (Daejung)용액 $50 \mu \mathrm{L}$ 를 넣어 반응을 종결시킨 다음 $405 \mathrm{~nm}$ 에서 microplate reader (Tecan Infinite M200 Pro; Green Mate Bio, Korea)를 이용하여 흡 광도를 측정한 후 다음의 식으로부터 저해율(\%)을 산출하였다.

Inhibition $(\%)=\left[1-\left(\mathrm{A}_{\text {Sample }}-\mathrm{A}_{\text {Blank }}\right) / \mathrm{A}_{\text {Control }}\right] \times 100$

$\mathrm{A}_{\text {Sample }}$ : 시료를 넣었을 때의 흡광도

$\mathrm{A}_{\text {Blank }}$ : 시료를 넣고 $p \mathrm{NPG}$ 를 넣지 않았을 때의 흡광도

$\mathrm{A}_{\mathrm{Control}}$ : 시료를 넣지 않았을 때의 흡광도

\section{Results and Discussion}

소비자가 선호하는 따뜻한 음료의 온도는 $62.8-68.3^{\circ} \mathrm{C}$ 이며 전 세계적으로 널리 음용되는 다류는 대부분 심리적인 안정감을 주 는 정서적 음료로 간주되고 있다(Borchgrevink et al., 1999). Ghasemzadeh-Mohammadi et al. (2017)에 따르면 차의 주요 화 학 성분은 저온에서 추출 시 더 효율적이며 추출 시 물의 온도가 $65^{\circ} \mathrm{C}$ 일때 카테킨 추출 수율이 가장 높다고 한다. Pramudya \& SeO (2018)는 $65^{\circ} \mathrm{C}$ 의 녹차가 낮은 온도의 녹차보다 감정적 반응과 감각 적 특성이 긍정적으로 나타났다고 한다. 이들의 연구결과를 참조하
여 본 연구에서는 차의 주요 화학 성분이 효율적으로 추출될 수 있으 며 소비자가 주로 선호하는 온도를 고려하여 열매차 추출물 제조 시 물의 온도를 $70^{\circ} \mathrm{C}$ 로 하였다.

\section{1. 국내 시판 열매차 추출물의 이화학적 특성}

1) Color value

국내 시판 열매차 추출물에 대한 외형사진과 색도 측정 결과는 Table 1에 나타내었다. 열매차 추출물의 색도는 투명한 것과 붉은색 및 갈색 색상을 지녔으며 깔라만시(calamansi)의 갈색 정도가 상대 적으로 가장 강했다. 열매차 추출물의 색상을 측정한 이유는 색상은 소비자가 음용하기 전 식욕을 돋우는 중요한 특성 중 하나로 본 연구 에서 분석한 열매차 추출물은 대부분 유색의 색상을 띄고 있으며 대 부분 엷은 갈색을 띄고 있었다. 적색도 결과는 외형사진에서 쉽게 관 찰할 수 있듯이 비트(beet)가 현저히 높은 값을 보였다. 황색도는 대 추(jujube)와 무(radish)가 각각 $28.46 \pm 0.19$ 와 $35.37 \pm 0.02$ 의 유의 적으로 높은 값을 나타내었다 $(p<0.05)$. 용액의 색상은 용출된 수용 성 색소들과 각종 차에 포함된 폴리페놀 화합물들 간의 중합이나 축 합반응이 색에 영향을 미치는 것으로 총 플라보노이드 함량이 높은 열매차 추출물이 전반적으로 유색을 띄고 있다는 것으로도 확인할 수 있었다.

\section{Table 2. The pH of commercial fruit teas extracted hot water at $70^{\circ} \mathrm{C}$}

\begin{tabular}{|c|c|c|}
\hline Name of fruit tea & $\mathrm{pH}$ & Liquid property \\
\hline Adzuki bean & $7.18 \pm 0.01^{1 / \mathrm{a} 2)}$ & basic \\
\hline Beet & $6.96 \pm 0.01^{c}$ & acidic \\
\hline Bitter gourd & $5.95 \pm 0.01^{g}$ & acidic \\
\hline Buckwheat & $7.17 \pm 0.01^{a}$ & basic \\
\hline Cacao nibs & $7.17 \pm 0.01^{a}$ & basic \\
\hline Calamansi & $3.05 \pm 0.01^{\circ}$ & acidic \\
\hline Cassia seed & $6.97 \pm 0.01^{c}$ & acidic \\
\hline Chaga mushroom & $7.08 \pm 0.01^{b}$ & basic \\
\hline Chinese quince & $4.54 \pm 0.01^{\mathrm{m}}$ & acidic \\
\hline Citron & $4.13 \pm 0.01^{n}$ & acidic \\
\hline Citrus unshiu peel & $6.96 \pm 0.01^{c}$ & acidic \\
\hline Jerusalem artichoke & $5.81 \pm 0.01^{h}$ & acidic \\
\hline Jujube & $6.48 \pm 0.01^{f}$ & acidic \\
\hline Lycii fructus & $5.05 \pm 0.01^{k}$ & acidic \\
\hline Noni & $5.04 \pm 0.01^{k}$ & acidic \\
\hline Oriental raisin tree & $5.80 \pm 0.01^{i}$ & acidic \\
\hline Radish & $5.65 \pm 0.01^{j}$ & acidic \\
\hline Rose hip & $4.69 \pm 0.01^{\prime}$ & acidic \\
\hline Safflower seed & $6.85 \pm 0.01^{d}$ & acidic \\
\hline Schizandra & $3.04 \pm 0.01^{\circ}$ & acidic \\
\hline Sword bean & $6.79 \pm 0.01^{\mathrm{e}}$ & acidic \\
\hline
\end{tabular}

${ }^{1)}$ Mean \pm S.D. $(\mathrm{n}=3) ;{ }^{2)}$ Means with different letters in the same column are significantly different at $p<0.05$ by Duncan's multiple range test. 
2) $\mathrm{pH}$

$\mathrm{pH}$ 측정 결과는 Table 2 와 같다. 식물체로부터 추출한 용액의 $\mathrm{pH}$ 는 추출물에 포함된 식물체에 포함된 유기산과 무기질의 종류와 양 에 따라 크게 영향을 받게 되는데 금속성 무기질의 경우 용액의 상태 를 알칼리 상태를 나타내며 비금속성 무기질의 경우는 산성의 상태 를 나타내게 한다. 21 종의 열매차 추출물의 $\mathrm{pH}$ 분석결과 팥, 메밀, 카카오닙스, 차가버섯 4종의 열매차 추출물 액성이 알칼리성(basic) 을 띄었고 그 외 나머지 열매 차는 모두 추출액이 산성(acidic)이었 다. 그중 오미자는 $\mathrm{pH}$ 가 $3.04 \pm 0.01$ 로 가장 낮은 값을 나타내었다. $\mathrm{pH}$ 가 낮은 액체의 경우 미생물의 정균작용(bacteriostatic effect)이 나 살균작용(bacteriocidal effect)이 있다는 것을 의미하는 것으로 $\mathrm{pH}$ 가 낮은 차류 추출물 이용하여 유통기한을 연장하는 방안에 대한 검토도 필요하다 생각된다.

\section{2. 열수추출 다류의 이화학적 특성}

\section{1) Total flavonoid content}

국내 시판 열매차 추출물에 대한 total flavonoid 함량을 분석한 결 과는 Table 3 과 같다. Total flavonoid 함량은 29.04 $1.49-217.87$ $\pm 1.45 \mathrm{mg} \mathrm{QE} / \mathrm{g}$ 범위의 값을 보였다. 깔라만시가 total flavonoid
함량이 가장 높았고, 카카오닙스가 유의적으로 가장 낮은 값을 나타 내었다 $(p<0.05)$. Flavonoid compound는 황색을 띄는 천연의 페놀 성 화합물로 자연계에서는 약 4,000 여 종류가 과일, 채소, 허브 등에 서 주로 발견되며 생체 내에서 유리라디칼(free radical)을 제거하고 인체의 산화 스트레스를 예방하며 혈장 지질 농도를 낮추는 역할을 한다고 알려져 있다(Alam et al., 2014). 이와 함께 염증 유발 유전 자 발현을 조절하는 기능과만성 염증으로 인한 동맥경화, 비만 및 당 뇨 등의 유병율을 감소시키는 유용한 물질이다(García-Lafuente et al., 2009). 본 연구에서 분석한 21 종의 국내 시판 열매차 추출물은 모두 플라보노이드 성분을 함유하고 있는 것으로 분석되어 비만을 비롯한 대사질환에 순작용(positive effect)을 할 수 있을 것으로 기대 된다.

\section{2) $D P P H$ radical 소거능}

$\mathrm{DPPH}$ 는 자색(purple color)을 띄는 비교적 안정한 물질로 환원되 면서 자체가 지닌 색이 탈색되는 현상을 이용하여 측정하는 것으로 항산화 물질의 존재여부를 알아보는 정성 또는 항산화 능력을 정량 적으로 측정하는 대표적인 분석법이다. $\mathrm{DPPH}$ 소거능이 높다는 것 은 인체내에 생성된 활성산소의 제거가 용이하여 결과적으로는 체내

Table 3. The total flavonoid content of commercial fruit teas extracted hot water at $70^{\circ} \mathrm{C}$

\begin{tabular}{|c|c|}
\hline Name of fruit tea & Total flavonoid content $\left.\left(\mathrm{mg} \mathrm{QE}^{1}\right) / \mathrm{g}\right)$ \\
\hline Adzuki bean & $38.02 \pm 0.99^{203)}$ \\
\hline Beet & $107.31 \pm 1.08^{f}$ \\
\hline Bitter gourd & $113.61 \pm 1.08^{\mathrm{e}}$ \\
\hline Buckwheat & $194.71 \pm 1.49^{c}$ \\
\hline Cacao nibs & $29.04 \pm 0.70^{9}$ \\
\hline Calamansi & $217.87 \pm 1.45^{\mathrm{a}}$ \\
\hline Cassia seed & $53.33 \pm 1.38^{\prime}$ \\
\hline Chaga mushroom & $208.19 \pm 1.24^{b}$ \\
\hline Chinese quince & $31.14 \pm 1.20^{p}$ \\
\hline Citron & $194.72 \pm 0.67^{c}$ \\
\hline Citrus unshiu peel & $90.22 \pm 1.33^{i}$ \\
\hline Jerusalem artichoke & $45.30 \pm 0.91^{\mathrm{m}}$ \\
\hline Jujube & $95.82 \pm 0.84^{h}$ \\
\hline Lycii fructus & $77.59 \pm 0.79^{k}$ \\
\hline Noni & $41.61 \pm 1.28^{n}$ \\
\hline Oriental raisin tree & $82.95 \pm 1.14^{j}$ \\
\hline Radish & $144.69 \pm 0.86^{d}$ \\
\hline Rose hip & $46.68 \pm 1.01^{\mathrm{m}}$ \\
\hline Safflower seed & $102.67 \pm 1.51^{\mathrm{g}}$ \\
\hline Schizandra & $31.09 \pm 0.93^{p}$ \\
\hline Sword bean & $40.24 \pm 0.68^{n}$ \\
\hline
\end{tabular}

${ }^{1)} \mathrm{QE}$, quercetin equivalent; ${ }^{2}$ Mean \pm S.D. $(\mathrm{n}=3) ;{ }^{3)}$ Means with different letters in the same column are significantly different at $p<0.05$ by Duncan's multiple range test. 
에서 발생하는 산화적 스트레스를 저감하여 인체의 노화를 방지하 는 효과가 있다는 걸 의미한다(Ancerewicz et al., 1998). 본 연구에 서 분석한 국내 시판 열매차 추출물에서는 그 정도의 차이는 있지만 $\mathrm{DPPH}$ radical 소거능은 있는 것으로 분석되었으며 DPPH radical 소거능 범위는 $93.91 \pm 0.47-4.31 \pm 1.32 \%$ 이었다. 로즈힙, 모과, 여 주, 깔라만시, 구기자는 $90 \%$ 이상의 높은 소거능을 보인 반면 메밀, 비트, 홍화씨의 DPPH 소거능은 상대적으로 낮은 소거능 값을 나타 내었다 $(p<0.05)$. 홍화씨의 DPPH 소거능 값이 가장 낮았다. Kim et al. (2016)에 따르면 항산화 활성에 폴리페놀성 화합물은 $84.6 \%$, 플 라보노이드는 $62.5 \%$ 기여한다고 하였으며, 폴리페놀과 플라보노이 드의 Pearson 상관관계를 분석한 결과는 0.688 로 플라보노이드가 폴 리페놀의 $68.8 \%$ 기여하는 것으로 보고한 바 있는데 본 연구에서 분석 한 열매차 추출물에서는 그와는 다소 상반된 양상을 나타내었다. 이는 Kim et al. (2016)의 연구에서 이용한 차류는 대부분 잎을 이용한 차 류에 대한 분석인 반면 본 연구에서는 열매를 이용한 열매차 추출물에 대한 연구로 차를 이용하는 부위에 따라 생리적 특성 및 항산화 특성 또한 다르게 나타난 것이라 판단된다.

\section{2) $\alpha$-Glucosidase 저해 활성}

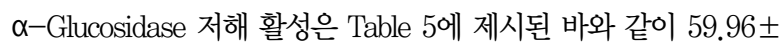

0.22- $1.01 \pm 0.41 \%$ 범위의 값을 보였다. 모과의 저해활성이 $59.96 \%$ 로 가장 높게 나타났으며 대추, 헛개나무, 오미자가 각각 $20 \%$, 차가 버섯, 홍화씨, 여주, 깔라만시, 노니, 카카오닙스, 귤피, 로즈힙 등 은 $10 \%$, 구기자, 무, 비트, 메밀, 작두콩, 유자, 결명자는 $10 \%$ 미 만의 $\alpha$-glucosidase 저해 활성을 보였다. 팥은 $1.01 \pm 0.41 \%$ 로 $\alpha$-glucosidase 저해 활성이 거의 없는 것으로 분석되었다.

식후 비정상적으로 증가된 포도당과 지질로 인한 식후 대사이상 증 (post-prandial dysmetabolism)은 산화적 스트레스를 유발하며, 족부 궤양 및 사지 절단, 실명, 심혈관 합병증, 신부전 등과 같은 여 러 합병증에 기여할 수 있는 제 2형 당뇨의 위험을 증가시킬 수 있다 (Zaharudin et al., 2019). 이런 경우 식후 혈장 포도당 수치를 조절하 기 위하여 탄수화물 분해 효소인 소장 $\alpha$-glucosidase를 억제하는 약 물로 아카보즈(acarbose)를 주로 처방하나 이로 인해 복통, 복부 팽만 증, 설사와 같은 위장 부작용이 발생된다고 보고되고 있다(Oh et al., 2015). 이에 따라 천연 물질에서 효과적이고 안전한 $\alpha$-glucosidase 억제제와 항산화 물질을 찾기 위한 많은 연구들이 이루어진 바 있으 며(Chen et al., 2009), Nagahora et al. (2013)은 열매류에서 가장 높은 $\alpha$-glucosidase 저해 활성을 보인 모과에는 풍부한 프로시아니 딘 성분을 함유하고 있어 당뇨와 당뇨로 인한 합병증에 효과적이라 고 보고한 바 있다. 본 연구에서도 건강을 생각하는 소비자들에게 이

Table 4. The DPPH radical scavenging activities of commercial fruit teas extracted hot water at $70^{\circ} \mathrm{C}$

\begin{tabular}{|c|c|}
\hline Name of fruit tea & DPPH radical scavenging activity (\%) \\
\hline Adzuki bean & $71.94 \pm 0.09^{1) \mathrm{g} 2)}$ \\
\hline Beet & $56.19 \pm 0.12^{k}$ \\
\hline Bitter gourd & $92.35 \pm 0.90^{\mathrm{ab}}$ \\
\hline Buckwheat & $60.61 \pm 0.69^{j}$ \\
\hline Cacao nibs & $68.15 \pm 1.10^{i}$ \\
\hline Calamansi & $92.17 \pm 0.71^{\mathrm{b}}$ \\
\hline Cassia seed & $70.15 \pm 0.41^{\mathrm{h}}$ \\
\hline Chaga mushroom & $60.71 \pm 0.20^{j}$ \\
\hline Chinese quince & $92.48 \pm 1.38^{\mathrm{ab}}$ \\
\hline Citron & $85.36 \pm 1.30^{d}$ \\
\hline Citrus unshiu peel & $80.60 \pm 0.01^{f}$ \\
\hline Jerusalem artichoke & $83.75 \pm 0.94^{e}$ \\
\hline Jujube & $89.61 \pm 1.07^{c}$ \\
\hline Lycii fructus & $91.78 \pm 0.16^{b}$ \\
\hline Noni & $71.57 \pm 1.54^{\text {gh }}$ \\
\hline Oriental raisin tree & $89.91 \pm 1.43^{c}$ \\
\hline Radish & $89.20 \pm 0.43^{c}$ \\
\hline Rose hip & $93.91 \pm 0.47^{\mathrm{a}}$ \\
\hline Safflower seed & $4.31 \pm 1.32^{\prime}$ \\
\hline Schizandra & $84.40 \pm 1.04^{\mathrm{de}}$ \\
\hline Sword bean & $82.06 \pm 1.01^{f}$ \\
\hline
\end{tabular}

${ }^{1)}$ Mean \pm S.D.(n=3); ${ }^{2}$ Means with different letters in the same column are significantly different at $p<0.05$ by Duncan's multiple range test. 
미 익숙한 모과, 대추, 헛개나무, 오미자와 같은 열매차 추출물에서 $\alpha$-glucosidase 저해활성이 높은 것으로 분석되었다. 이상의 결과를 종합해 볼 때 한가지 종류가 아닌 항산화 활성이 우수한 원료를 이용 한 블랜딩 차류 제품제조 시 상승효과(synergy effect)가 있는가에 대 한 추가적인 평가와 제품 표준화에 관한 연구가 이루어지는 것이 바람 직할 것으로 판단된다.

\section{Conclusion}

본 연구는 국내 다소비 열매차 21종에 대한 이화학적 특성과 항산 화 활성을 분석하여 차후 가공식품 개발 시 기초자료를 확보하고자 하 였다. 열매차 추출물 제조를 위한 물의 온도는 소비자의 선호도, 유효 성분의 효율적 추출에 적합한 $70^{\circ} \mathrm{C}$ 에서 추출을 진행하였고 이렇게 추 출한 열매차 추출물의 이화학적 특성으로는 외관, 색도, $\mathrm{pH}$ 를 측정 하였고 항산화 활성과 관련해서는 총 플라보노이드, $\mathrm{DPPH}$ 소거능, $\alpha$-glucosidase 저해 활성을 비교분석하였다.

이화학적 특성에 대한 분석 결과 열매차 추출물의 외관은 투명색과 붉은색, 갈색 색상을 띄었고 그중 갈색이 가장 많았고 깔라만시의 갈 색 정도가 가장 강했다. $\mathrm{pH}$ 결과에서는 오미자의 $\mathrm{pH}$ 가 $3.04 \pm 0.01$ 로
가장 낮았으며 대부분의 열매차 추출액은 산성의 성질을 지니고 있었 다.

항산화 활성 관련 열매차 추출물의 총 플라보노이드 함량 분석 결 과는 29.04 $1.49-217.87 \pm 1.45 \mathrm{mg} \mathrm{QE} / \mathrm{g}$ 범위를 보였으며 깔라만 시가 가장 높은 값을 나타내었고 카카오닙스가 가장 낮았다. $\mathrm{DPPH}$ radical 소거능에서는 로즈힙, 모과, 여주, 깔라만시, 구기자는 $90 \%$ 이 상의 높은 소거능 결과를 보였다. $\alpha-G$-Gucosidase 저해 활성은 모과, 대추, 헛개나무, 오미자에서 상대적인 $\alpha$-glucosidase 저해 활성이 높 은 것으로 분석되었다. 이상의 결과를 이용하여 짐작해 볼 때 항산화 활성에 대한 기초자료를 확보할 수 있었으며 향후 블랜딩 열매차류 개 발 시 유용한 자료로의 활용도 기대할 수 있을 것으로 판단된다.

\section{Author's contribution}

K.A.J and H.M.R. designed all experimental design. H.A.R collected literature and contributed to all aspects of analysis and experiment. H.A.R and H.M.R. wrote the manuscript with assistance from K.A.J.

\section{Author details}

Ah-Ra Hwang (Graduate student), Department of

Table 5. The $\alpha$-glucosidase inhibitory activities of commercial fruit teas extracted hot water at $70^{\circ} \mathrm{C}$

\begin{tabular}{|c|c|}
\hline Name of fruit tea & $\alpha$-Glucosidase inhibitory activity (\%) \\
\hline Adzuki bean & $1.01 \pm 0.41^{1 / j 2)}$ \\
\hline Beet & $7.93 \pm 0.52^{\text {gh }}$ \\
\hline Bitter gourd & $14.27 \pm 1.64^{\mathrm{e}}$ \\
\hline Buckwheat & $7.17 \pm 0.94^{h}$ \\
\hline Cacao nibs & $13.59 \pm 1.13^{\mathrm{e}}$ \\
\hline Calamansi & $14.20 \pm 1.50^{\mathrm{e}}$ \\
\hline Cassia seed & $3.34 \pm 1.22^{i}$ \\
\hline Chaga mushroom & $18.21 \pm 0.69^{d}$ \\
\hline Chinese quince & $59.96 \pm 0.22^{a}$ \\
\hline Citron & $4.12 \pm 0.74^{i}$ \\
\hline Citrus unshiu peel & $11.50 \pm 0.38^{f}$ \\
\hline Jerusalem artichoke & $10.79 \pm 1.62^{f}$ \\
\hline Jujube & $25.26 \pm 1.36^{b}$ \\
\hline Lycii fructus & $9.58 \pm 1.38^{\mathrm{fg}}$ \\
\hline Noni & $13.92 \pm 1.63^{\mathrm{e}}$ \\
\hline Oriental raisin tree & $25.12 \pm 1.76^{b}$ \\
\hline Radish & $8.27 \pm 1.10^{\text {gh }}$ \\
\hline Rose hip & $11.35 \pm 0.15^{f}$ \\
\hline Safflower seed & $15.38 \pm 0.03^{\mathrm{e}}$ \\
\hline Schizandra & $20.23 \pm 1.75^{c}$ \\
\hline Sword bean & $4.61 \pm 0.90^{i}$ \\
\hline
\end{tabular}

${ }^{1)}$ Mean \pm S.D. $(\mathrm{n}=3) ;{ }^{2}$ Means with different letters in the same column are significantly different at $p<0.05$ by Duncan's multiple range test. 
Alternative Medicine, Kyonggi University, 24, Kyonggidaero, 9-gil, Seodaemun-gu, Seoul 03746, Korea; MyungRyun Han (Professor), Department of Baking Science \& Technology, Hyejeon College, 25, Daehak-gil, Hongseongeup, Hongseong-gun, Chungcheongnam-do 32244, Korea; Ae-Jung Kim (Professor), Department of Nutrition Therapy, Graduate School of Alternative Medicine, Kyonggi University, 24, Kyonggidae-ro, 9-gil, Seodaemun-gu, Seoul 03746, Korea.

\section{References}

Alam MA, Subhan N, Rahman MM, Uddin SJ, Reza HM, Sarker SD. Effect of citrus flavonoids, naringin and naringenin, on metabolic syndrome and their mechanisms of action. Advances in Nutrition, 5: 404-417, 2014.

Ancerewicz J, Migliavacca E, Carrupt PA, Testa B, Bree F, Zini R, Tillement JP, Labidalle S, Guyot D, Chauvet-Monges AM, Crevat A, Le Ridant A. Structure-property relationships of trimetazidine derivatives and model compounds as potential antioxidants. Free Radical Biology and Medicine, 25: 113-120, 1998.

Blois MS. Antioxidant determination by the use of a stable free radical. Nature, 181: 1199-1200, 1958.

Borchgrevink CP, Susskind AM, Tarras JM. Consumer preferred hot beverage temperatures. Food Quality and Preference, 10: 117-121, 1999.

Cao J, Zhao Y, Li Y, Deng HJ, Yi J, Liu JW. Fluoride levels in various black tea commodities: measurement and safety evaluation. Food and Chemical Toxicology, 44: 11311137, 2006.

Chen H, Qu Z, Fu L, Dong P, Zhang X. Physicochemical properties and antioxidant capacity of 3 polysaccharides from green tea, oolong tea, and black tea. Journal of Food Science, 74: C469-474, 2009.

Davis WB. Determination of flavanones in citrus fruits. Analytical Chemistry, 19: 476-478, 1947.

Fang CY, Wang XJ, Huang YW, Hao SM, Sheng J. Caffeine is responsible for the blood glucose-lowering effects of green tea and Puer tea extractsin BALB/c mice. Chinese Journal of Natural Medicines, 13: 595-601, 2015.

García-Lafuente A, Guillamón E, Villares A, Rostagno MA, Martínez JA. Flavonoids as anti-inflammatory agents: implications in cancer and cardiovascular disease. Inflammation Research, 58: 537-552, 2009.

Ghasemzadeh-Mohammadi V, Zamani B, Afsharpour M, Mohammadi A. Extraction of caffeine and catechins using microwave-assisted and ultrasonic extraction from green tea leaves: an optimization study by the IV-optimal design. Food Science and Biotechnology, 26: 1281-1290, 2017.

Graham HN. Green tea composition, consumption, and polyphenol chemistry. Preventive Medicine, 21: 334-350, 1992.

Grundy SM, Cleeman JI, Daniels SR, Donato KA, Eckel RH, Franklin BA, Gordon DJ, Krauss RM, Savage PJ, Smith SC, Spertus JA, Fernando C. Diagnosis and management of the metabolic syndrome; an American heart association/ national heart, lung, and blood institute scientific statement; executive summary. Current Opinion in Cardiology, 4: 198-203, 2006.

Imran A, Butt MS, Arshad MS, Arshad MU, Saeed F, Sohaib M, Munir R. Exploring the potential of black tea based flavonoids against hyperlipidemia related disorders. Lipids in Health and Disease, 17: 1-16, 2018.

Jung YH, Han JS, Kim AJ. Quality evaluation and antioxidant activity of inner beauty tea prepared from roasted lotus root and burdock. Asian Journal of Beauty and Cosmetology, 17: 235-245, 2019.

Kim MG, Oh MS, Jeon JS, Kim HT, Yoon MH. A study on antioxidant activity and antioxidant compound content by the types of tea. Journal of Food Hygiene and Safety, 31: 132-139, 2016.

Kim SY, Kozukue N, Han JS, Lee KR. Catechins, theaflavins and methylxanthins contents of commercial teas. Korean Journal of Food and Cookery Science, 21: 346-353, 2005.

Ko MS, Park HS. Analysis on the state of taking tea and related factors among college students. Association for International Tea Culture, 36: 1-20, 2017.

Lee SY, Kim MJ, Kim AJ. Mulberry and peppermint leaves mixing ratio optimization for skin beauty. Asian Journal of Beauty and Cosmetology, 19: 379-393, 2021.

Legeay S, Rodier M, Fillon L, Faure S, Clere N. Epigallocatechin gallate: a review of its beneficial properties to prevent metabolic syndrome. Nutrients, 7: 5443-5468, 2015.

Levantesi G, Macchia A, Marfisi R, Franzosi MG, Maggioni AP, Nicolosi GL, Schweiger C, Tavazzi L, Tognoni G, Valagussa 
F, Marchioli R. GISSI-Prevenzione Investigators. Metabolic syndrome and risk of cardiovascular events after myocardial infarction. Journal of the American College of Cardiology, 46: 277-283, 2005.

Li T, Zhang X, Song Y, Liu J. A microplate-based screening method for $\alpha$-glucosidase inhibitors. Chinese Journal of Clinical Pharmacology and Therapeutics, 10: 1129-1131, 2005.

Liu L, Nagai I, Gao Y, Matsushima Y, Kawai Y, Sayama K. Effects of catechins and caffeine on the development of atherosclerosis in mice. Bioscience, Biotechnology, and Biochemistry, 81: 1948-1955, 2017.

Moon JH, Park KH. Department of food science and technology. Journal of Korean Tea Society, 1: 175-191, 1995.

Morelli NR, Scavuzzi BM, Miglioranza LHDS, Lozovoy MAB, Simão ANC, Dichi I. Metabolic syndrome components are associated with oxidative stress in overweight and obese patients. Archives of Endocrinology and Metabolism, 62: 309-318, 2018.

Nagahora N, Ito Y, Nagasawa T. Dietary Chinese quince polyphenols suppress generation of $\alpha$-dicarbonyl compounds in diabetic KK-A(y) mice. Journal of Agricultural and Food Chemistry, 61: 6629-6635, 2013.

Oh JB, Jo SH, Kim Justin S, Ha KS, Lee JY, Choi HY, Yu SY, Kwon YI, Kim YC. Selected tea and tea pomace extracts inhibit intestinal $\alpha$-glucosidase activity in vitro and postprandial hyperglycemia in vivo. International Journal of Molecular Sciences, 16: 8811-8825, 2015.

Pramudya RC, Seo HS. Influences of product temperature on emotional responses to, and sensory attributes of, coffee and green tea beverages. Frontiers in Psychology, 2264: 1-16, 2018.

Rösen P, Nawroth PP, King G, Möller W, Tritschler HJ, Packer L. The role of oxidative stress in the onset and progression of diabetes and its complications: a summary of a congress series sponsored by UNESCO-MCBN, the American diabetes association and the german diabetes society. Diabetes/Metabolism Research and Reviews, 17: 189212, 2001.

Shin Y, Kim SD, Kim BS, Yun ES, Chang MS, Jung SO, Lee YC, $\mathrm{Kim} \mathrm{JH}$, Chae YZ. The content of minerals and vitamins in commercial beverages and liquid teas. Journal of Food Hygiene and Safety, 26: 322-329, 2011.

Snoussi C, Ducroc R, Hamdaoui MH, Dhaouadi K, Abaidi H, Cluzeaud F, Nazaret C, Le Gall M, Bado A. Green tea decoction improves glucose tolerance and reduces weight gain of rats fed normal and high-fat diet. The Journal of Nutritional Biochemistry, 25: 557-564, 2014.

Yoo IS, Park JM, Kim AJ. Evaluation of the physicochemical activities of frequently consumed edible flower teas in Korea. Asian Journal of Beauty and Cosmetology, 19: 289-301, 2021.

Van De Wier B, Koek GH, Bast A, Haenen GR. The potential of flavonoids in the treatment of non-alcoholic fatty liver disease. Critical Reviews in Food Science and Nutrition, 57: 834-855, 2017.

Zaharudin N, Staerk D, Dragsted LO. Inhibition of $\alpha$-glucosidase activity by selected edible seaweeds and fucoxanthin. Food Chemistry, 270: 481-486, 2019. 


\section{국문초록}

\section{국내 시판 열매차 추출물의 품질 특성}

황아라 ${ }^{1}$, 한명륜 ${ }^{2}$, 김애정 ${ }^{*}$

${ }^{1}$ 경기대학교 대체의학대학원 식품치료전공, 서울, 한국

${ }^{2}$ 혜전대학교 제과제빵학과, 충청남도 홍성군, 한국

목적: 본 연구의 목적은 한국에서 다소비 되고 있는 21 가지의 열매를 이용한 차 추출물의 이화학적 특성과 항산화 활성을 분석하여 열매를 이용한 가공제품 개발 시 필요한 기초자료를 마련하고자 하였다. 방법: $70^{\circ} \mathrm{C}$ 의 온수 추출물의 색도, $\mathrm{pH}$ 등의 이화학적 특 성을 분석했으며 항산화 활성 관련 총 플라보노이드 함량과 $\mathrm{DPPH}$ 소거능 및 $\alpha$-glucosidase 저해 활성을 측정하였다. 결과: 명도 는 깔라만시가 가장 낮았고 적색도는 비트, 황색도는 대추와 무가 유의적으로 높은 것으로 나타났다. $\mathrm{pH}$ 는 3.04 에서 7.18까지로 분 석되었고 대부분 산성 상태를 나타내었다. 그중 오미자차의 $\mathrm{pH}$ 가 $3.04 \pm 0.01$ 로 가장 낮았다. 총 플라보노이드 함량은 깔라만시가

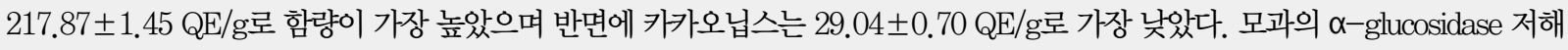
활성이 $59.96 \pm 0.22 \%$ 로 가장 높은 것으로 분석되었다. 결론: 본 연구를 통해 열매차 추출물의 이화학적 특성과 생리활성을 분석하 여 기초 자료를 확보할 수 있었으며 이 결과가 차후 블랜딩 열매차 제품 개발 시 효과적인 자료로 활용되기를 기대한다.

핵심어: 차, 열매차, 시판차, 이화학적 특성, 항산화 특성

\section{참고문헌}

고민석, 박희선. 대학생의 차 음용 현황과 관련요인 분석. 국제차문화학회지, $36: 1-20,2017$.

김명길, 오문석, 전종섭, 김한택, 윤미혜. 다류의 유형별 항산화 성분함량 및 항산화 활성 연구. 한국식품위생안정성학회 지, 31: 132-139, 2016.

김수연, 小机信行, 한재숙, 이갑랑. 시판 차류의 catechins, theaflavins 및 methylxanthins 함량에 관한 연구. 한국식품 조리학회지, 21: 346-353, 2005.

신영, 김성단, 김복순, 윤은선, 장민수, 정선옥, 이용철, 김정현, 채영주. 유통음료 및 액상차 중의 비타민과 미네랄 함량. 한국식품위생안정성학회지, 26: 322-329, 2011.

유인서, 박지민, 김애정. 한국에서 다소비 되고 있는 식용꽃차의 생리활성. 아시안뷰티화장품학술지, 19: 289-301, 2021.

이신영, 김민주, 김애정. 피부 미용을 위한 뽕잎과 페퍼민트잎의 혼합비율 최적화 연구. 아시안뷰티화장품학술지, 19 : 379-393, 2021.

정연희, 한정순, 김애정. 로스팅한 연근과 우엉을 이용한 이너 뷰티 차의 항산화 활성과 품질 평가. 아시안뷰티화장품학술

지, 17: 235-245, 2019. 


\section{中文摘要}

\section{韩国商品果茶提取物的品质特性}

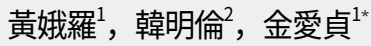

1京畿大学代替医疗大学院食品治疗学科, 首尔, 韩国

慧田大学烘焙科学与技术学科, 忠清南道洪城郡, 韩国

目的: 评估在韩国消费的 21 种果茶提取物的理化特性和抗氧化活性。对数据进行分析和整理, 以用于未来 使用茶的加工产品的开发。方法: $70^{\circ} \mathrm{C}$ 热水提取后, 分析其颜色、 $\mathrm{pH}$ 值等理化性质, 以及抗氧化活性（总黄 酮含量、DPPH清除能力、 $\alpha$-葡萄糖苷酶抑制活性）。结果：卡拉曼西茶的亮度最低, 外观呈甜荣红色, 柊 和夢卜的黄色明显更高。 $\mathrm{pH}$ 值范围为 3.04 至 7.18 , 大多数样品处于酸性状态。其中, 五味子茶的 $\mathrm{pH}$ 值最 低, 为3.04 00.01 。总黄酮含量在鱿鱼中最高, 为 $217.87 \pm 1.45 \mathrm{QE} / \mathrm{g}$, 而可可豆粒的总黄酮含量最低, 为 $29.04 \pm 0.70 \mathrm{QE} / \mathrm{g}$ 。榅桲的 $\alpha$-葡萄糖苷酶抑制活性最高, 为 $59.96 \% \pm 0.22 \%$ 。结论: 通过分析理化性质和抗氧化 活性, 我们获得了几种果茶提取物的基本数据。我们预计这些结果将代表用于茶产品开发的混合水果的有用数 据。

关键词: 茶，果茶，商品茶，理化性质，抗氧化性质 
